This item was submitted to Loughborough's Research Repository by the author.

Items in Figshare are protected by copyright, with all rights reserved, unless otherwise indicated.

\title{
Social capital in a syndicate investment platform - Effects on syndicate lead performance
}

\section{PLEASE CITE THE PUBLISHED VERSION}

https://www.babson.edu/academics/centers-and-institutes/the-arthur-m-blank-center-for-

entrepreneurship/babson-college-entrepreneurship-research-conference/2019-bcerc---babson-college/

\section{PUBLISHER}

(C) The authors. Published by Babson College

\section{VERSION}

AM (Accepted Manuscript)

\section{PUBLISHER STATEMENT}

This work is made available according to the conditions of the Creative Commons Attribution-NonCommercialNoDerivatives 4.0 International (CC BY-NC-ND 4.0) licence. Full details of this licence are available at: https://creativecommons.org/licenses/by-nc-nd/4.0/

\section{LICENCE}

CC BY-NC-ND 4.0

\section{REPOSITORY RECORD}

Zhang, Y., Louise Scholes, Kun Fu, and Mathew Hughes. 2020. "Social Capital in a Syndicate Investment Platform - Effects on Syndicate Lead Performance". Loughborough University. https://hdl.handle.net/2134/37811. 


\title{
Social Capital in a Syndicate Investment Platform - Effects on Syndicate Lead Performance
}

\begin{abstract}
Investors on equity crowdfunding platform often face an information asymmetry problem due to the lack of information on assessing the true value of new ventures (Agrawal, Catalini, \& Goldfarb, 2016). Moreover, average crowd investors may be either unqualified or unwilling to conduct the requisite due diligence. Equity crowdfunding syndicates emerged in recent years as an innovative form of entrepreneurial financing to overcome these challenges. They serve as a way for "syndicate leads" to leverage their knowledge and bring in substantial funds from a crowd of "backers" (Agrawal et al., 2016). Syndicate leads source investments and secure allocations of funds for investment while conducting due diligence. In exchange, backers pay the syndicate lead a fee (carried interest) for any subsequently profitable investment. This whole process is facilitated on platforms such as AngelList and SyndicateRoom.

Despite the growing popularity of equity crowdfunding syndicates, scholarly understanding of the phenomenon is currently limited. Prior research shows equity crowdfunding syndicates shift the focal investment activities of the crowd from startups to syndicate leads (Agrawal et al., 2016). Given the important role played by syndicate leads, it is vital to develop theory-based understandings of their performances. Our study uses social capital theory to examine the effects of syndicate leads' social capital within and beyond the platform on the performance of syndicate leads. Using data from a sample of 181 syndicate leads on AngelList, a world leading equity crowdfunding platform in the US, our study offers two contributions to social capital literature in the entrepreneurial finance context. First, we differentiate syndicate platform with non-syndicate platform social capital, based on the categories of bonding/internal social capital and bridging/external social capital (Adler \& Kwon, 2002). Second, we build upon multidimensional social capital theory and distinguish syndicate leads' social capital into structural, relational and cognitive aspects (Nahapiet and Ghoshal, 1998). This study represents a first attempt to understand this new form of entrepreneurial financing. We provide a research model with related hypotheses for how syndicate platform multidimensional social capital and non-syndicate platform multidimensional social capital of syndicate leads are related to their performance.
\end{abstract}

\section{Syndicate platform multidimensional social capital}

The syndicate platform serves more than as a financing channel and features as a privileged forum for the creation of social contacts (Butticè, Colombo, \& Wright, 2017). We define syndicate platform social capital as an internal "bonding" type of social capital that establishes through interactions with other members within the syndicate platform and is composed of three dimensions (Nahapiet and Ghoshal, 1998). The structural dimension reflects network ties that provide access to resources and constitutes a valuable source of information benefits. We propose that the degree of syndicate leads' social network ties in syndicate platform is positively associated with their performances. The relational dimension represents the degree of trust, identity and obligation. The mechanism of equity crowdfunding syndicate rely upon backers' trust that the interests of the syndicate leads are fully aligned with their own and that the syndicate lead is actually able to select, monitor, and support 
high-quality deals (Agrawal et al., 2016). Thus, we argue the trust generated from syndicate platform social network is positively associated with performance of syndicate leads. We define cognitive dimension as degree of common grounds and values with other members on the syndicate platform and argues it brings and keeps trust relationship (Barber, 1983). We expect that the degree of syndicate leads' common grounds with other members on the platform is positively associated with their performance.

\section{Non-syndicate platform multidimensional social capital}

Social contacts also exist outside a syndicate platform and we define non-syndicate platform social capital as an external "bridging" type of social capital that derives from syndicate leads' interactions and relationships with others outside the boundary of the syndicate platform. Social network ties outside the syndicate platform allow syndicate leads reaching to more potential entrepreneurs and diversifying their portfolios. So we propose the degree of syndicate leads' non-syndicate platform social network ties is positively associated with their performances. The trust generated beyond syndicate platform affects what kind of investment opportunities syndicate leads access to (Sørheim, 2003). Therefore, we propose that the trust generated from non-syndicate platform social network is positively associated with performances of syndicate leads. Syndicate leads who largely share their value and narratives to others will stimulate further cooperation. We define non-syndicate platform cognitive social capital of syndicate leads as the degree of their common grounds with other members outside syndicate investment platform and propose that it is positively associated with their performances.

\section{Methods and Results}

Our study draws on two sources of data: the equity crowdfunding syndicate platform AngelList to capture syndicate platform social capital, and professional social network LinkedIn to capture non-syndicate platform. We use number of connections, number of backers and number of people syndicate leads followed to measure the structural, relational, and cognitive dimensions of syndicate leads' syndicate platform social capital. Number of followers, number of references received and number of influencers followed by syndicate leads to measure the three dimensions of non-syndicate platform social capital. We use the number of deals syndicated in the last 12 months to measure their performances.

Preliminary results shows syndicate leads' syndicate platform relational and cognitive social capital are positively associated with their performances, and surprisingly, syndicate leads' non-syndicate platform structural social capital is negatively associated with their performances. Syndicate platform structural, non-syndicate platform relational and cognitive social capital of syndicate leads have no effect on their performances. 